Article

\title{
An Economic Analysis of Corporate Social Responsibility in Korea
}

\author{
Daeheon Choi ${ }^{1}$, Chune Young Chung ${ }^{2, *}$ and Jason Young ${ }^{3}$ \\ 1 College of Business Administration, Kookmin University, 77 Jeongneung-ro, Seongbuk-gu, \\ Seoul 02707, Korea; dhchoi@kookmin.ac.kr \\ 2 School of Business Administration, College of Business and Economics, Chung-Ang University, \\ 84 Heukseok-ro, Dongjak-gu, Seoul 06974, Korea \\ 3 College of Business, Washington State University, Pullman, WA 99164, USA; qwertied@naver.com \\ * Correspondence: bizfinance@cau.ac.kr; Tel.: +82-2-820-5544
}

Received: 29 November 2018; Accepted: 7 May 2019; Published: 10 May 2019

check for updates

\begin{abstract}
Around the globe, socially responsible activities are being integrated into regulations, and corporate social responsibility (CSR) is increasingly being recognized as a means of sustaining a business and improving its competitiveness. South Korea has made a significant effort to encourage CSR activities in order to increase its firms' competitive advantage. This study evaluates the sustainable development activities of Korean firms, and empirically analyzes the positive impact of CSR on corporate performance (CP) in Korea over a period of four years. A comparison by industry reveals that CSR has a greater impact on CP in the manufacturing sector than it does in the nonmanufacturing and service sectors. Furthermore, the results for consumption goods are more positive than those for industrial goods, because the former are, in general, more affected by customer feedback. A case study of three Korean firms was used to examine CSR implementation in Korea, recent activities undertaken by Korean firms, and the integration of CSR concepts into firms' strategies.
\end{abstract}

Keywords: corporate social responsibility; corporate performance; Korea

\section{Introduction}

With firms increasingly required to undertake socially responsible activities, corporate social responsibility (CSR) has received much attention related to attracting and sustaining a business. In this context, South Korea has made a significant effort to implement CSR activities. Of 200 corporations in South Korea, recorded by total revenue, more than $86 \%$ currently promote CSR activities, and $97 \%$ now realize the need for socially responsible activities [1]. Furthermore, the perception of CSR activities is expanding; in addition to donations and contributions to society, CSR is now considered an essential method for business sustainability, both nationally and internationally.

Because the definition of corporate social responsibility varies depending on the researcher, it has no single conceptual definition. However, according to the widely regarded study on CSR [2,3], the fundamental social responsibility of corporations is to provide sufficient employment to the labor force, while generating a profit by manufacturing and/or selling products and/or offering services. However, apart from these fundamental social responsibilities, many argue that firms should employ CSR activities to create a positive corporate image. In general, developed countries understood the importance of this first. As a result, CSR activities began earlier in such countries than they did in developing countries. For example, Matsuda Electronic. Co, a large Japanese electronics corporation, arranged for a professional CSR team to improve the firm's ability to implement CSR activities and, thus, its sustainability. Matsuda Electronic called this initiative "PDCA: Plan, Do, Check, Action" [2]. 
Corporations can benefit in several ways by participating in society. First, doing so promotes balanced development through investment in local areas. In addition, building trust between a firm and its customers creates a positive corporate image, which can increase the firm's profit [3-5]. Furthermore, volunteering improves the capabilities of labor and enhances relations between firms and unions, thus reducing conflict (e.g., "Doosan Infracore" in South Korea). Some believe that volunteering also increases the understanding between seniors and the volunteers, thus increasing the latter's loyalty to the firm [6].

The expenditure on social contributions per total revenue by South Korean firms is relatively small compared with those of other developed nations [7]; thus, firms' CSR activities are closely related to their sustainability and competence. Furthermore, social activity increases firms' profits, leading to continual investments in CSR [8] and profit $[9,10]$. This is because CSR activities lead to consumers developing a positive perception about a firm, which helps to sustain the business. Research between 1972 and 2002 in 127 countries shows a strong correlation between CSR performance and financial performance, with a positive corporate image playing an important role in this relationship [11,12].

Studies on CSR activities are now investigating strategic philanthropy (cause-related marketing) [12,13], that is, the importance of CSR to a firm's strategy. Refer to the cited works for examples of how CSR has benefited companies.

In the Korean market, $87 \%$ (or 30) of the firms with the highest sales plan to invest more in CSR than they did in 2014. In addition, $86 \%$ of the firms consider CSR sources as key performance indicators (KPIs), although the market conditions have not yet been well generated. Moreover, several large Korean companies have announced that they are going to increase their CSR investments over time by means of, for example, social contribution programs, donation programs by CEOs, and using a proportion of their increased profit for CSR costs.

This study empirically evaluates Korean corporations' CSR activities by examining the relationship between such activities and corporate performance (CP) from 2012 to 2015. The Korean market is an especially interesting setting in which to study CSR, because it is dominated by chaebols. Chaebols are typically controlled by family members, who have significant power over business operations and, thus, are prone to self-interested and short-term-oriented behavior at the expense of outside shareholders and other stakeholders. This unique market environment enables us to fill an important gap in the literature on CSR and firm value. Based on Chung et al. [7], many Korean firms have long been under the influence of Chaebols (i.e., Korean version of family-oriented business conglomerate). According to the Korea Fair Trade Commission, Chaebol firms, such as the Samsung, Hyundai, LG, Doosan, and GS groups, comprise 61 business conglomerates and 1696 subsidiary companies as of April 2015. Their total market value exceeds KRW 2258 trillion, and they account for a substantial proportion of the firms listed on Korea Exchange (KRX). Chaebol-affiliated firms are largely controlled by their owner-manager, and, thus, the board of directors is generally comprised of insiders and friends of the Chaebol families and corporate decision making exhibits low transparency. This weak internal governance mechanism in Chaebol-affiliated firms allows managers to achieve their own goals at the expense of other stockholders. Hence, a CSR mechanism could be more influential on corporate decision making in the Korean market and is likely to affect firm value.

This study is the first to examine the extent to which CSR activities benefit Korean firms' CP. Although many studies have examined the effect of CSR on CP, the results are still inconclusive, with some even arguing that CSR activities do not produce any benefits for companies. For example, according to the earlier studies $[1,12]$ examining the relationship between CSR and financial performance did not provide the same results as those derived from the recent studies, in that they found that there was no significantly positive association between CSR and financial performance. In addition, the findings of Lee [11] were not successful in identifying the true relationship between CSR and CP based on a sample from 1992 to 1995. It rather shows a weak negative relationship. However, An [13] found a significantly positive relationship between CSR and corporate performance based on the sample period of 1998 to 2007. This study makes a novel contribution to the CSR literature by using data that 
are not yet analyzed extensively. In particular, we use the Korea Economic Justice Institute (KEJI)-CSR index (CSR), a CSR index developed by the Citizens' Coalition for Economic Justice (CCEJ), as a proxy for a firm's CSR activities. The KEJI-CSR index is the single most credible CSR index, and it can be used for academic research and annual Good Corporation Awards, which are provided by the CCEJ. The KEJI-CSR index evaluates firms based on seven categories: financial soundness, fairness, social charity/aid, consumer protection, environmental commitment, employee satisfaction, and contribution to economic development. the KEJI-CSR index is comparable to the Dow Jones Sustainability Korea Index (DJSI Korea) constructed in 2009, which represents the top 30\% of the 200 largest South Korean companies in the S\&P Global BMI based on long-term economic, environmental, and social criteria. Both indexes concern financial soundness, environmental and social issues, human capital development, employee satisfaction, and donations related to social contributions.

\section{Literature Review}

\subsection{Definitions and Process}

The concept of CSR entered into management research in the 1930s, and again after the Vietnam War in the 1960s. CSR grew in importance with marked changes in the environment and in the values of society [14]. Many CSR experts note that Bowen was the first to research CSR in 1953, in his book Social Responsibility of Corporations. The book states that "Corporations have an obligation for doing business activities ethically, such as in corporation policies and decision-making, compared with social purpose and values" [15]. Many current researchers base their definitions of CSR on Carroll's definition, according to which CSR activities can be classified into four groups: economic responsibility, legal responsibility, ethical responsibility, and philanthropic responsibility [3]. According to McGuire et al., "Corporate Social Responsibility should not only be the basis for the economic and legal aspects of society, but also for its overall development" [16]. Porter and Kramer insist that CSR is a strategic concept, based not on cost factors, but on the principle of innovation, opportunities, and competing advantages [17]. Dahlsurd notes that CSR has 37 definitions, usually based on five criteria: stakeholders, society, economy, voluntariness, and environment. Furthermore, it is important to consider changes in business strategies rather than using a standard definition of CSR [18]. In addition to these academic sources, many international organizations define CSR activity. These include the Organization for Economic Cooperation and Development (OECD), the European Union (EU), and the International Labor Organization (ILO). In general, the World Business Council for Sustainable Development (WBCSD) and EU definitions are cited as in Table 1. The WBCSD states that "corporations should conduct their business ethically and support economic development, and firms also need to improve balanced development among citizens be consistent geographically." On similar lines, the EU defines CSR as "the concept of integrating society within interaction among shareholders of social and economic organizations" [18].

CSR arises from the needs of the time. Some follow the concept and ideological thoughts from Carnegie's The Gospel of Wealth [19]. Academic research on CSR begins with the philosophical argument that corporates have an obligation to improve the status of society [20]. On the other hand, recent trends include corporate citizenship and sustainable development. The criteria for CSR and the reasons why firms undertake CSR activities are explained by the views of classical economics and social economics, respectively. Classical economics views profit maximization as the social responsibility of firms. Thus, seeking to maximize profits is important to the promising legal limitation. Economists believe that the fundamental responsibility of owners is to consider shareholders' profits. Friedman mentions that profit maximization is the only way for corporates to conduct social responsibility successfully and to sustain a society free of status; thus, other CSR activities should be opposed [21]. Levit identifies the dangers of social responsibility in 1958 in the Harvard Business Review, explaining that an over-enforcement of CSR activities might harm firms. 
Table 1. Definitions of CSR.

\begin{tabular}{|c|c|c|}
\hline & Concept & Definition \\
\hline UNCTAD & CSR & Corporations' reaction and impact on society's requirement and goal \\
\hline OECD & CR & $\begin{array}{l}\text { Corporations' action for developing and promoting relationship between firms } \\
\text { and society }\end{array}$ \\
\hline EU & CSR & Corporations' responsibility for impact on society \\
\hline ILO & CSR & $\begin{array}{l}\text { Without legal responsibility, it is an initiative for firms' activities to impact on } \\
\text { all shareholders }\end{array}$ \\
\hline ISO & SR & $\begin{array}{l}\text { Organizations' activities for providing benefits, and resolving economic, social, } \\
\text { and environmental problems of people and the local community }\end{array}$ \\
\hline WBCSD & CSR & Corporations' volition to improve all social participants' quality of living standards \\
\hline
\end{tabular}

* UNCTAD: United Nations Conference on Trade and Development; ISO: International Organization for

Standardization; <Source: Ministry of Foreign Affairs and Trade' report, 2011>.

From a social economics viewpoint, companies should consider both profit maximization and protecting and improving public wealth, because firms are not sustainable without social members: enterprises comprise socially promised legal sources and are politically secure. In addition, firms need well-educated employees from society, who later purchase the firms' products or use their services. Therefore, firms are also social members and, thus, should receive benefits from society. A representative study of social membership is that of Carroll, whose ideas were actively discussed in the 1960s and the 1970s. As a result, a four-level model was created for estimating corporate social achievement, as shown in Table 2.

Table 2. Carroll's CSR, four-level model.

\begin{tabular}{cc}
\hline Level 4. Charitable Responsibility & $\begin{array}{c}\text { Compulsory Responsibility to be actively pursued by Corporates } \\
->\text { Social contribution }\end{array}$ \\
\hline Level 3. Ethical Responsibility & $\begin{array}{c}\text { Responsibility that Corporates should be keep and follow } \\
->\text { Ethical Management }\end{array}$ \\
\hline Level 2. Legal Responsibility & $\begin{array}{c}\text { Basic reason for existence of Corporates } \\
\text { Level 1. Economical Responsibility }\end{array}$ \\
\hline
\end{tabular}

Source: Do, E (2005).

\subsection{CSR in South Korea}

The interest in CSR activities in South Korea began in earnest in the mid-1990s [22]. Prior to this, CSR referred to corporations' social contributions and donations for social purposes [23]. More recently, these activities have come to include profitable actions that increase companies' revenue. Because firms spend significant amounts of money on CSR, these activities should now be an important part of firms' strategies. For example, according to the Federation of Korea Industries, firms' expenditure on CSR activities has gradually increased since 2002 and is now more than 3\% of ordinary income. In addition, Korean firms have expanded their expenditure on scholarships, donations, and supporting the poor by more than KRW 2 thousand billion, which indicates the importance of CSR within corporate strategies [24]. For example, the Federation of Korea Industries created "the 1 percent club" to provide a perception of CSR activities to society. In this way, they built a participating atmosphere and a national scale with its distribution. This helped Korean firms to participate and cooperate voluntarily in CSR activities [24]. With the expansion of CSR trends, in 2009, 17 Korean companies were recorded in the DJSI World Index, which measures the sustainability of 317 corporations, researched by 2500 firms. Nevertheless, some experts argue that Korean firms still do not realize the importance of CSR activities as a vital strategy [19]; whereas the United States and EU treat CSR as an investment, South Korea still considers it a tax action implemented as a reaction to social pressure [25]. 
In addition, the South Korean government has implemented several policies related to CSR, with social responsibility teams being formed to promote socially beneficial activities (see Table 3 ).

Table 3. South Korea's CSR policies.

\begin{tabular}{ll}
\hline 1. & Enhancing sustainable development and supporting expand the concepts within country \\
\hline 2. & Legalized the sustainable development \\
\hline 3. & Various studies and surveys on CSR \\
\hline 4. & Responds for ISO international standards \\
\hline
\end{tabular}

\subsection{CSR Performance Index (KEJI Index)}

Corporations' economic performance has been measured in a variety of business and economic studies, with the profitability of corporations often used for evaluations. However, measures of social performance vary. A brief summary of the social performance measures used by organizations is provided in Table 4.

Table 4. Evaluation clauses of countries' organizations.

\begin{tabular}{lllll}
\hline Name & $\begin{array}{l}\text { Corporate Environmental } \\
\text { Performance (USA) }\end{array}$ & Ernst \& Young (UK) & Bilan Social (France) & KEJI (Korea) \\
& Environment conservation & Ecosystem and environment & Economic & -Profits \\
& Sexual Equality & Consumer protection & -Products & Integrity \\
& Race Equality & Local community & Satisfaction of workers & Fairness \\
& Donation & Relationship with government & -Working conditions & Social performance \\
Evaluation & Welfare & Corporation donation & -Wages & Consumer protection \\
Clauses & Working environment & Race equality & -Training & Environment conservation \\
& Information clarity & Relationship among firms, & Social, local community & \\
& Animal protection & workers, and shareholders & -Environmental improvement & \\
& Local community & Economic activities & -Consumer satisfaction & \\
& Social problem & 1971 & 1977 & 1991 \\
\hline Initiate Year & 1969 & <Source: Citizens Coalition for Economic Justice, 2016>. &
\end{tabular}

The Citizens' Coalition for Economic Justice (CCEJ) has published the Korea Economic Justice Index (KEJI) every year since 1991, focusing on manufacturing companies listed on the Korean stock market. The index considers six categories to enable objective CSR research by professors, research institutes, and the government, among others. Moreover, while conducting the survey, the national administrative agency, parliament, and consumer organizations' data are also included in this evaluation system. The evaluation clauses are as shown in Table 5.

Several changes occurred to the KEJI in 2012. First, the "Economic commitment" clause was deleted, because it was not important when evaluating CSR performance, and financial corporations were added. Since 2012, the KEJI has been accompanied by the International Standard Organization 26000 (ISO26000), which is an international social responsibility organization. Therefore, the changes made to the KEJI clauses are consistent with the clauses of ISO26000 [26,27].

Table 5. KEJI evaluation clauses.

\begin{tabular}{cl}
\hline Evaluation Clauses & \multicolumn{1}{c}{ Evaluation Index } \\
\hline Integrity & Shareholder, investment, and capital procurement \\
Fairness & Fairness, clarity, and relationship with others \\
Social performance & Protection of neglected class of people and supporting social welfare \\
Consumer protection & Protection for consumer rights, product quality, and advertisement \\
Environment conservation & Commitment for environment improvement, result of environmental \\
Employees & commitment, and cases of illegal environment actions \\
& Investment for human resources, company benefits packages, gender equality, etc. \\
\hline & Source: Citizens' Coalition for Economic Justice, 2016.
\end{tabular}




\subsection{CSR with Firm Performance}

Although the importance of CSR has been investigated thoroughly, few firms participate actively in CSR in many countries. However, since 2007, several studies have compared CSR with CP. Turban and Greening [28] mention that CSR makes some employees work harder, which attracts potential applicants to CSR firms. According to Peterson [29], a company's positive reputation, constructed by CSR activities, make employees more loyal to the firm, and thus more focused on their work. According to Dawkins [30], more than half of the employees or applicants to firms prefer those with positive CSR. In addition, in past research, the mediating effect of firms' ethics codes, perceived ethical values, and perceived sources means that ethical business activities contribute to the work ethic of firms' employees [31]. In general, in shareholder theory, a CSR activity is as an ethical activity that helps to resolve relationship conflicts between shareholders and companies, thus reducing corporations' costs and risks. A few studies have found that CSR activities improve a firm's market valuation, and that CSR investments are evaluated by market participants in Asian countries [32]. However, relatively few studies on the Korean market provide meaningful implications for CSR researchers and investors in the Asian region. In particular, the success of Korean firms and the country's rapid economic growth has been disproportionately credited to market participants. As a result, stakeholders are increasingly demanding that firms protect their rights and meet their social responsibilities [33]. In response to these demands, corporate investment in CSR activities is growing in Korea [34], and managers are becoming more aware of their social duties [35]. In particular, since the 1997 Asian financial crisis, government authorities and investors have placed greater pressure on Korean firms to engage in CSR activities, for example, by forcing firms to invest in CSR-related projects [36]. In addition, the study [37] documents that firms voluntarily pay attention to CSR activities in order to enhance their social reputation. The literature [38] shows that, in the Korean market, the CSR-firm value nexus is largely influenced by the ownership structure of the firm.

Many previous studies in Korea have compared CSR with firms' financial performance. The study [39] used the "1992 KEJI" to examine the relationship between CSR and financial performance, but their results differ from those of more recent studies, in that they find no close association between CSR and financial performance. This finding is supported by the literature [40], based on a sample for the period 1992 to 1995. However, the study [41] found a significant relationship between CSR and CP, as in studies on developed countries, using a sample for the period 1995 to 1998 . Related literature [42] concluded that corporations' legal, ethical, and volunteering activities produce a positive relationship with customers, and that consumers also place greater trust in the products of such firms and evaluate the businesses positively. Studies on CSR and financial performance published in other countries have shown that environmental performance and firms' profits have a positive correlation [43]. Another study [44] used an overall social evaluation index to confirm that a firm's return on assets (ROA) and CSR activities have a positive correlation. Yet another study [45] examined listed and unlisted firms, finding that CSR activities have a greater impact on listed firms, in financial terms, implying that shareholders' CSR activities have a positive correlation with CP. Based on these results, this study empirically evaluates the relationship between CSR activities (using the KEJI) and financial performance (using the ROA and Tobin's Q, indicating a firm's present and future values, respectively).

In particular, this study adds to the recent literature that examines CSR activities and firm performance. A study documents that sustainability reporting practice is positively associated with firm value, based on Singapore-listed companies [46]. In addition, the positive relationship between sound CSR practices and firm value is found in Hong Kong and China as well [47]. Recently literature [48] corroborates the positive influence of CSR activities on firm value.

\subsection{Previous Research on CSR}

Prior research on CSR has used various methods. Studies $[49,50]$ document that corporate environmental effort is positively associated with financial performance. More recently, study [51] 
shows that the relationship between nonfinancial reporting/environmental strategies and corporate financial performance is positive. In addition, another finding [52] presents a systematic overview of the costs of CSR. Study [53] also validates the conceptual model for creating a sustainability report in small to mid- sized enterprises, using case studies. Using the regression discontinuity approach, one finds that CSR tends to lead to superior financial performance and the other documents that social capital and trust are more valuable during a financial crisis [54,55].

In South Korea, research on CSR is divided into two general categories: theoretical normative research on CSR, and positive research. The former includes historical studies on CSR in South Korea [19,39], policies and routine CSR activities in South Korea [40-42], a comparison between US and South Korean CSR [43], and the future of CSR research [44].

Positive research on the association between CSR and firm performance is commonly found in the fields of finance, marketing, and accounting. In finance, much of the research has focused on the correlation between CP and CSR performance in terms of cost reduction [45], revenues and profitability [46,47], sustaining development [45,48], and management efficiency [49]. In accounting, most are related to the relationship between CSR and the invisibility of accounting [50,51]. In marketing, many experts have studied consumer behavior based on CSR activities and corporate image. Some have examined the relationship between CSR activities and customers' credits and their loyalty to a CSR firm, as well as the effect of CSR activities on a brand's image [56,57]. These studies have begun to create an objective index with which to measure CSR activities by area, such as evaluating performance $[57,58]$. In order to promote research on CSR in South Korea, many studies concentrate on the three parts of positive research, namely, the inside capability of a firm, management structure, and environmental factors, as viewed by shareholders [44].

With the rapid changes in the positive trend of CSR activities worldwide, many organizations have implemented CSR policies to improve their sustainability. In particular, the condition of renewing the ISO26000 certification has been gradually enforced by global stakeholders and citizens, increasing the amount of positive research on global CSR. Therefore, a country's global and local CSR activities are needed to explain the combined effect of CSR. Research on global CSR activities has largely been conducted by each nation. South Korea's global CSR activities have been published in China, a popular destination for foreign direct investment by South Korean firms [58,59]. A representative comparison study between countries is that comparing Japan and Korea in terms of CSR [48]. However, the only general study on South Korean firms' global CSR activities outside the country is a global CSR strategy study [49]. Thus, a combination of local cases and South Korea's global CSR strategies is needed to understand how CSR activities offer more than merely developing resources, and how they can help resolve economic and social crises.

Importantly, the study [39] shows that the CSR-firm value nexus is largely influenced by the ownership structure of a firm, based on the Korean market. In addition, the Korean market is an especially interesting setting in which to study CSR, because it is dominated by chaebols. Chaebols are typically controlled by family members, who have significant power over business operations and, thus, are prone to self-interested and short-term-oriented behavior, at the expense of outside shareholders and other stakeholders. This unique market environment enables us to fill an important gap in the literature on CSR and firm value.

\section{Research Method}

\subsection{Hypotheses}

This study proposes two hypotheses:

(1) CSR and CP are correlated.

(2) The impact of CSR varies by industry. 


\subsubsection{CSR with CP}

The first hypothesis has three dimensions: CSR has a positive/negative correlation with CP, or there is no correlation between the two. Most recent studies insist that CSR has a positive relationship with CP. However, some argue that social activities are not relevant to a company's performance. Therefore, this study examines the relationship between CSR and the KEJI for the period 2012 to 2015.

Hypothesis (1):

(1-1): CSR is correlated with the ROA.

(1-2): CSR is correlated with Tobin's Q.

\subsubsection{CSR Impact by Industry}

Many global studies mention that the impact of CSR on CP varies depending on the industrial characteristics [21]. Thus, the approach to CSR should vary by industry. For example, service and consumption industries are more affected by the public's perception, which might be constructed from the companies' social activities. On the other hand, industrial and manufacturing businesses are less affected by public perception. Therefore, this study examines the impact on CP of CSR, by industry.

Hypothesis (2):

(2-1): CSR has a different effect on each industry's CP.

(2-2): The impact of CSR on the manufacturing industry is greater than that on the service sector.

(2-3): CSR affects consumption goods more than it does industrial goods.

\subsection{Data}

The data samples are gathered as follows:

(1) All samples were downloaded from the Korea Exchange for the period 2012 to 2015.

(2) All samples exist in the current market and in the KEJI.

(3) All data are gathered from "TS2000 from 2012 to 2015".

(4) Financial businesses are not included in the sample.

The final sample contains 639 items. From 2012, the evaluation clauses change slightly, in that the "economic contribution" part is no longer included separately. Therefore, four years' data (2012-2015; see Table 6) are chosen to enable a more precise analysis. With regard to the industry categories, TS2000 provides data on 49 industries, including manufacturing, service, and construction businesses. This study also considers Korea Standard Industrial Classification (KSIC-9) data, which are updated every year. Many previous studies, other than those on CSR, have used this classification to ensure compatibility between results. It is published by Statistics Korea, and is usually divided into nine categories, as shown in Table 7. Most samples fall within the manufacturing (488) and metal and nonmetal/chemical (211) sectors in the KSIC-9 and KEJI, respectively (see Table 8).

Table 6. Sample data.

\begin{tabular}{cccccc}
\hline Year & $\mathbf{2 0 1 2}$ & $\mathbf{2 0 1 3}$ & $\mathbf{2 0 1 4}$ & $\mathbf{2 0 1 5}$ & Sum \\
\hline $\mathrm{N}$ & 90 & 179 & 186 & 184 & 639 \\
\hline
\end{tabular}


Table 7. Industry (KSIC-9, financial businesses not included).

\begin{tabular}{cc}
\hline Industry & N \\
\hline Manufacturing & 488 \\
Electronic/Gas/Steam/Water & 28 \\
Construction & 7 \\
Wholesale/Retail & 40 \\
Transportation & 19 \\
Publishing/Media/Broadcasting/Information Service & 19 \\
Professional, Scientific, Technological Service & 33 \\
Other & 5 \\
\hline
\end{tabular}

Table 8. Industry (KEJI, financial businesses not included).

\begin{tabular}{ccccc}
\hline Industry & $\begin{array}{c}\text { Non- } \\
\text { Manufacturing/Service }\end{array}$ & $\begin{array}{c}\text { Food and } \\
\text { Drug/Clothing/Paper/Woods }\end{array}$ & $\begin{array}{c}\text { Metal and } \\
\text { Non-Metal/Chemical }\end{array}$ & Electronics/Mechanics \\
\hline $\mathrm{N}$ & 124 & 138 & 211 & 166 \\
\hline
\end{tabular}

\subsection{Variations}

\subsubsection{CSR Evaluation}

This study proposes using the KEJI quantitative score as the CSR score:

$$
\mathrm{CSR}=\mathrm{KEJI} \text { Index's quantitative score }
$$

The Economic Justice Institute in the Citizens Coalition of Economic Justice evaluates the KEJI's quantitative score. This index score has several advantages over other CSR score data, because it is objective and uses official material. Second, the KEJI has been used to evaluate firms since 1991, thus providing a significant amount of data. Third, research is promoted because the data include categorized studies. As a result, many previous studies have used KEJI data [47].

\subsection{2. $\mathrm{CP}$}

To evaluate a firm's CP, this study uses the ROA as an accounting measure, and Tobin's Q for financial terms, both of which satisfy the sample condition. This method has been used in a variety of studies to calculate CP.

To analyze corporations' financial performance, Tobin's $Q[24,42,53]$ is measured. Tobin's $Q$ is estimated when a firm's retained market assets are divided into replacements, and there is a low possibility of fabricating results, such as depreciation. Furthermore, this is useful for comparing firms, and has the advantage of predicting future profits [37]. However, because it is not possible to calculate an asset's replacements, this study does so using the equity asset book value and market value ratio, as suggested by the study [52]. In general, a Tobin's Q greater than one is positive, less than one is negative, and equal to one is moderate.

Tobin's $Q=($ Ordinary share market capitalization + preferred stock capitalization $)+$ liabilities/assets

To estimate a firm's accounting performance, the ROA is used:

$$
\text { ROA }=\text { Business profits/(first of term asset }+ \text { end of term asset }) * 100
$$

To understand the relationship between CSR and CP, some sources are controlled, which might be controlled into CP. Size and the liabilities ratio (Lev) are used as control variables, following previous studies [37]. 
The reason for controlling size is that companies might be able to realize scale economies, enabling them to outperform smaller firms. Moreover, society's requirements of firms vary with the sizes of firms $[34,37,38]$.

$$
\text { Size }=\log (\text { asset })
$$

This "Liabilities ratio" indicates the corporation's degree of dependence on other capital, and thus the degree of risk, which may affect the company's performance. This is calculated using total assets and total liabilities [34,36,37], as follows:

$$
\text { Lev }=(\text { total liabilities/total assets }) * 100
$$

In particular, the explanatory variables are constructed as follows. For firm i in year $t$, Size is the natural logarithm of sales, and Lev is the total debt divided by the market value of equity (common shares outstanding multiplied by the stock price). Previous studies document that CSR is related to a firm's performance, liquidity, risk, and size. The study $[34,38]$ report that a firm's size predicts CSR, because a larger firm is more likely to be subjected to external pressure. The literature [39] suggests that financial slack also affects CSR activities.

\subsection{Research Model}

$$
\begin{gathered}
\mathrm{CP}=\alpha+\beta \mathrm{CSR}+\beta \text { Size }+\beta \text { Lev }+\varepsilon \\
\mathrm{CP}=\text { Corporate Performance } \\
\mathrm{CSR}=\text { KEJI evaluation score } \\
\text { Size }=\log (\text { Total assets }) \\
\text { Lev }=\text { Liabilities } / \text { Total assets }
\end{gathered}
$$

\section{Results of Empirical Research}

\subsection{Hypothesis 1}

\subsubsection{Descriptive Statistics and Correlation}

This research uses data covering four years, from 2012 to 2015, yielding a sample of 639 items. Industries are further divided into four sectors, based on the KEJI: (1) Nonmanufacturing/Service; (2) Food and Drug/Clothing/Paper/Woods; (3) Metal and Nonmetal/Chemicals; and (4) Electronics/Mechanics.

Then, to understand the extent to which the industry works in the market, two other industrial categorizations are used to compare industries: (a) Service/Nonmanufacturing with manufacturing; and (b) Industrial goods and consumption items. The descriptive statistics for the multiple regression analysis are shown in Table 9.

Table 9 provides the descriptive statistics for the research sample, where the average ROA is $4.68 \%$, and the average Tobin's $Q$ is 1.57 . This sample simply indicates that Tobin's $Q$ is more than one, which means that this is a positive value for future development. The average quantitative score, which represents each company's CSR evaluation, is 63.84 out of 75 . 
Table 9. Descriptive statistics.

\begin{tabular}{cccc}
\hline & AVERAGE & S.D & N \\
\hline CSR & 63.84 & 2.35 & 639 \\
ROA & 4.68 & 3.94 & 639 \\
TOBIN'S Q & 1.57 & 2.71 & 639 \\
SIZE & 5.57 & 0.86 & 639 \\
LEV & 36.97 & 17.44 & 639 \\
\hline
\end{tabular}

\subsubsection{Correlation between CSR and CP (ROA and Tobin's Q)}

From the results, Tobin's $Q$ is seen to have a close positive correlation with CSR (0.161) and ROA $(0.160)$ at the $1 \%$ significance level. In addition, with the control variables, Size and Lev are correlated with Tobin's $Q$ at the $1 \%$ and $5 \%$ significance levels, respectively.

Table 10 shows that, at the $1 \%$ significance level, with all variables, including the control variables, the ROA has a somewhat strong correlation with CSR (0.284), Tobin's Q (0.160), Size (0.282), and Lev (-0.258).

Table 10. Correlation results between CSR and CP (ROA and Tobin's Q).

\begin{tabular}{cccccc}
\hline & CSR & ROA & TOBIN'S Q & SIZE & LEV \\
\hline CSR & 1 & & & \\
ROA & $0.284^{* *}$ & 1 & 1 & & \\
TOBIN'S Q & $0.161^{* *}$ & $0.160^{* *}$ & $0.121^{* *}$ & 1 & \\
SIZE & $0.181^{* *}$ & $0.282^{* *}$ & $-0.086^{*}$ & 0.048 & 1 \\
LEV & $-0.083^{*}$ & $-0.258^{* *}$ & -0.0 & \\
\hline \multicolumn{7}{c}{$: 5^{* *}: 1 \%}$.
\end{tabular}

\subsubsection{Regression Analysis between CSR and CP}

The results are shown in Table 11. Tobin's $Q$, which indicates the relationship between CSR and a firm's financial performance, shows that the F-value is 9.040 as the $1 \%$ significance level. The empirical research shows that CSR has a positive effect on Tobin's $Q$ at the $1 \%$ significance level (0.158). This means that with higher CSR scores, the possibility of positive financial results is higher. For the control variables, size is positive, implying that, for larger companies, the effect of CSR on Tobin's $Q$ increases. Lev is negative, which means that a higher Lev does not help to increase the CSR efforts of the sample firms.

Table 11. Regression (CSR and CP).

\begin{tabular}{ccc}
\hline DV & ROA & TOBIN'S Q \\
\hline Intercept & $\begin{array}{c}-22.958^{* * *} \\
(-5.946)\end{array}$ & $\begin{array}{c}-9.816^{* * *} \\
(-3.373)\end{array}$ \\
\hline CSR & $\begin{array}{c}0.364^{* * *} \\
(5.979)\end{array}$ & $\begin{array}{c}0.158^{* * *} \\
(3.440)\end{array}$ \\
\hline SIZE & $1.168^{* * *}$ & $0.317^{* *}$ \\
& $(7.040)$ & $(2.532)$ \\
\hline LEV & $-0.057^{* * *}$ & $-0.012^{* *}$ \\
& $(-7.072)$ & $(-2.028)$ \\
\hline IND & Included & Included \\
\hline F-VALUE & $52.489 * * *$ & $9.040^{* * *}$ \\
\hline \multicolumn{2}{c}{$* *: 5 \%, * *: 1 \%,():$ t-value. }
\end{tabular}

In terms of the ROA, which indicates a firm's financial performance, the F-value is 52.489 at the $1 \%$ significance level. Here, CSR has a positive effect on the ROA of 0.364 at the $1 \%$ significance level, 
indicating that the ROA and CSR have a positive relationship. For the control variables with the ROA, as in the case of Tobin's $Q$, size shows a strong correlation with the ROA (1.168) at the $1 \%$ significance level, but Lev has a negative correlation (-0.057).

Therefore, the regression analysis shows that the CP, considered using CSR, over the four years is positive. This result proves hypothesis (1), and that CSR benefits firms' $\mathrm{CP}$, supporting the findings of other studies [13].

Considering the control variables, whereas size has a positive relationship with $\mathrm{CP}$, Lev does not. A comparatively large firm can realize economies of scale or of scope more easily than smaller firms can. However, to explain the result for Lev, with a high debt ratio, most firms would avoid increasing their costs, such as CSR [53].

\subsection{Hypothesis 2}

Results by Industry

Although the results show that CSR and CP have a positive correlation, individual industries may exhibit varying effects on CP by CSR. Therefore, several views of the empirical research are needed in the evaluation study. First, the study considers four industry categories based on the KSIC-9. In the KSIC-9, most firms fall within the manufacturing sector $(76.9 \%)$, with some samples having less than 20 firms, which might be unacceptable for a comparison. Therefore, this is referred to as the KEJI industrial classification. Unfortunately, the number of firms in the sample is less than 20; hence, this category is not included in the empirical study. Furthermore, using the KSIC-9 classification, this study could not identify any specialties to mention in the text. (The results of the KSIC-9 regression indicate that they are unacceptable for analysis.) Owing to the reasons mentioned above, this study uses the KEJI classification of nonconsumption goods/services, food and drug/clothing/paper/wood, metal and nonmetal/chemical, and electronics/mechanic.

As shown in Panel A of Table 12, there are some differences in the regression analysis. In terms of the ROA by industry, all industries show a positive correlation with CSR performance at the 5\% significance level for nonconsumption goods/services (0.286), and at the $1 \%$ significance level for metal and nonmetal/chemical (0.416), electronics/mechanic (0.518), and food and drug/clothing/paper/wood (0.321). In Penal B, for Tobin's Q with CSR, except for food and drug/clothing/paper/wood, the results prove that that CSR increases a firm's value. Food and drug/clothing/paper/wood indicates no significance, although the result is positive. These results show that CSR activities have a significant effect on all industries, and that the metal and nonmetal/chemical sector benefits most overall ( 0.416 for ROA and 0.286 for Tobin's $Q$ at the $1 \%$ significance level).

The control variables can be explained by industry. With regard to nonmanufacturing goods/services, size does not match Tobin's Q and the ROA in terms of the effect of CSR on CP. However, in Tobin's Q, this would reduce each firm's Lev. For food and drug/clothing/paper/wood, both control variables are affected in that size with ROA (1.677) is shown to strongly affect the ROA in all four years. Furthermore, CSR helps to decrease Lev in all four years, by as much as -0.080 . Similarly, in the food and drug/clothing/paper/wood and electronics/mechanics industries, for the ROA, both control variables affect the accounting performance in terms of achieving a higher CP volume by CSR. For the metal and nonmetal/chemical industry, the control variables affect the results in that Lev has a strong impact on the CSR results for CP. In addition, Tobin's Q by size is somewhat affected at the $10 \%$ significance level.

Overall, CSR and the ROA have a significant effect on each other over the four years, more so than Tobin's $Q$ in each industry. The results for the control variables, size and the liabilities ratio, for the electronics/mechanics and food and drug/clothing/paper/wood industries vary by ROA. These results support Hypothesis (2-1). Furthermore, the nonmanufacturing/service industry is more affected than other industries are, as explained by Hypothesis (2-2). Therefore, the next regression compares the manufacturing and nonmanufacturing/service industries. 
Table 12. Regression on ROA and Tobin's Q (Industrial differences).

\begin{tabular}{|c|c|c|c|c|}
\hline $\begin{array}{l}\text { Panel A: } \\
\text { ROA }\end{array}$ & $\begin{array}{l}\text { Nonmanufacturing/ } \\
\text { Service }\end{array}$ & $\begin{array}{c}\text { Food and Drug/Clothing/ } \\
\text { Paper/Woods }\end{array}$ & $\begin{array}{c}\text { Metal and NonMetal/ } \\
\text { Chemical }\end{array}$ & $\begin{array}{l}\text { Electronics/ } \\
\text { Mechanics }\end{array}$ \\
\hline Intercept & $\begin{array}{l}-16.428^{* *} \\
(-2.018)\end{array}$ & $\begin{array}{l}-22.304^{* * *} \\
(-3.180)\end{array}$ & $\begin{array}{l}-21.141^{* * *} \\
(-3.249)\end{array}$ & $\begin{array}{c}-36.554 * * * \\
(-4.134)\end{array}$ \\
\hline CSR & $\begin{array}{c}0.286 * * \\
-2.2\end{array}$ & $\begin{array}{l}0.321^{* * *} \\
-3.001\end{array}$ & $\begin{array}{c}0.416^{* * *} \\
-3.95\end{array}$ & $\begin{array}{c}0.518^{* * *} \\
-3.718\end{array}$ \\
\hline SIZE & $\begin{array}{c}0.48 \\
-1.04\end{array}$ & $\begin{array}{l}1.677^{* * *} \\
-6.4\end{array}$ & $\begin{array}{c}0.397 \\
(-2.477)\end{array}$ & $\begin{array}{l}1.851^{* * *} \\
-4.874\end{array}$ \\
\hline LEV & $\begin{array}{l}-0.001 \\
(-0.081)\end{array}$ & $\begin{array}{l}-0.080 * * * \\
(-5.600)\end{array}$ & $\begin{array}{l}-0.076^{* * *} \\
(-4.486)\end{array}$ & $\begin{array}{l}-0.060 * * * \\
(-3.479)\end{array}$ \\
\hline F-VALUE & $2.544 *$ & $35.752 * * *$ & $14.532^{* * *}$ & $18.643^{* * *}$ \\
\hline \multicolumn{5}{|c|}{$*: 10 \%,{ }^{* *}: 5 \%,{ }^{* * *}: 1 \%,():$ t-value. } \\
\hline $\begin{array}{l}\text { Panel B: } \\
\text { Tobin's Q }\end{array}$ & $\begin{array}{c}\text { Non- } \\
\text { Manufacturing/Service }\end{array}$ & $\begin{array}{c}\text { Food and } \\
\text { Drug/Clothing/Paper/Woods }\end{array}$ & $\begin{array}{c}\text { Metal and } \\
\text { Non-Metal/Chemical }\end{array}$ & $\begin{array}{l}\text { Electronics/ } \\
\text { Mechanics }\end{array}$ \\
\hline Intercept & $\begin{array}{l}-12.049 * \\
(-1.830)\end{array}$ & $\begin{array}{l}-1.994 \\
(-0.552)\end{array}$ & $\begin{array}{l}-18.032 * * \\
(-2.518)\end{array}$ & $\begin{array}{l}-3.912 * \\
(-1.840)\end{array}$ \\
\hline CSR & $\begin{array}{l}0.199 * \\
-1.829\end{array}$ & $\begin{array}{c}0.039 \\
-0.715\end{array}$ & $\begin{array}{l}0.286^{* *} \\
-2.429\end{array}$ & $\begin{array}{l}0.072 * * \\
-2.151\end{array}$ \\
\hline SIZE & $\begin{array}{l}0.396 \\
-1.06\end{array}$ & $\begin{array}{c}0.156 \\
-1.156\end{array}$ & $\begin{array}{l}0.571 * \\
-1.856\end{array}$ & $\begin{array}{c}0.083 \\
-0.904\end{array}$ \\
\hline LEV & $\begin{array}{l}-0.025 * \\
(-1.883)\end{array}$ & $\begin{array}{c}0.001 \\
-0.123\end{array}$ & $\begin{array}{l}-0.038 * * \\
(-2.173)\end{array}$ & $\begin{array}{c}0.002 \\
-0.498\end{array}$ \\
\hline F-VALUE & $3.627^{* *}$ & 0.676 & $5.399 * * *$ & $2.172 *$ \\
\hline
\end{tabular}

Table 13 compares the manufacturing and nonmanufacturing/service industries. CP by CSR has a greater impact on manufacturing businesses than it does on the nonmanufacturing/service industry. This is closely related to Hypothesis (2-2), and can be explained by the consumption goods that are part of the manufacturing industry. A previous study $[27,28]$ notes that the consumption goods industry is sensitive to public reaction. In contrast, for industrial products, creating public preferences is difficult; thus, the firms' CP with CSR is lower than that of other businesses. This question is examined using two additional criteria, namely, consumption goods and industrial items. Consumption goods are divided further into free consumption goods and essential consumption goods, industrial goods are divided into energy, materials, and industrial items, and "other" is divided into medical, financial, information and technology, telecommunication, utility, and fund services.

Table 13. Regression (Service/Nonmanufacturing and Manufacturing/etc.).

\begin{tabular}{|c|c|c|c|c|}
\hline \multirow[b]{2}{*}{ DV } & \multicolumn{2}{|c|}{ Service/Nonmanufacturing } & \multicolumn{2}{|c|}{ Manufacturing/etc. } \\
\hline & ROA & TOBIN'S Q & ROA & TOBIN'S Q \\
\hline Intercept & $\begin{array}{c}-16.397^{* *} \\
(-1.981)\end{array}$ & $\begin{array}{c}-11.855 * \\
(-1.769)\end{array}$ & $\begin{array}{c}-25.578^{* * *} \\
(-5.905)\end{array}$ & $\begin{array}{c}-9.710^{* * *} \\
(-2.971)\end{array}$ \\
\hline CSR & $\begin{array}{c}0.285^{* *} \\
-2.157\end{array}$ & $\begin{array}{l}0.196 \text { * } \\
-1.826\end{array}$ & $\begin{array}{c}0.410 * * * \\
-5.99\end{array}$ & $\begin{array}{c}0.154^{* * *} \\
-2.983\end{array}$ \\
\hline SIZE & $\begin{array}{c}0.471 \\
-1.822\end{array}$ & $\begin{array}{c}0.406 \\
-1.072\end{array}$ & $\begin{array}{c}1.216^{* * *} \\
-6.835\end{array}$ & $\begin{array}{c}0.306^{* *} \\
-2.283\end{array}$ \\
\hline LEV & $\begin{array}{c}0 \\
-0.11\end{array}$ & $\begin{array}{l}-0.025 * \\
(-1.910)\end{array}$ & $\begin{array}{c}-0.073^{* * *} \\
(-7.886)\end{array}$ & $\begin{array}{c}-0.009 \\
(-1.324)\end{array}$ \\
\hline F-VALUE & $2.426^{*}$ & $3.570 * *$ & $54.540^{* * *}$ & $6.391^{* * *}$ \\
\hline
\end{tabular}


Table 14 documents that the impact of CSR on the ROA and Tobin's $Q$ is positive at the variable significance levels. In particular, for consumption goods, the coefficient is highest in this sector (at the $1 \%$ significance level), with 0.517 for the ROA and 0.233 for Tobin's Q. Compared with other businesses, this industry is the most efficient in terms of using CSR to achieve better CP. The results for industrial goods are also positive for CP with CSR in terms of both the ROA and Tobin's Q. However, the relative impact is not as high as that of consumption goods. Consequently, Hypothesis 2(3) is established.

Table 14. Regression (Consumption Goods, Industrial Goods, etc.).

\begin{tabular}{ccccccc}
\hline DV & ROA & \multicolumn{5}{c}{ Tobin's Q } \\
\hline Industry & $\begin{array}{c}\text { Consumption } \\
\text { Goods }\end{array}$ & $\begin{array}{c}\text { Industrial } \\
\text { Goods }\end{array}$ & etc. & $\begin{array}{c}\text { Consumption } \\
\text { Goods }\end{array}$ & $\begin{array}{c}\text { Industrial } \\
\text { Goods }\end{array}$ & etc. \\
\hline Intercept & $-34.763^{* * *}$ & - & - & $-15.151^{* * *}$ & $-2.553^{*}$ & - \\
& $(-5.894)$ & $\begin{array}{c}16.046^{* * *} \\
(-2.595)\end{array}$ & $\begin{array}{c}16.983^{*} \\
(-1.955)\end{array}$ & $\begin{array}{c}(-2.702) \\
(-1.203)\end{array}$ & $\begin{array}{c}12.928^{*} \\
(-1.801)\end{array}$ \\
\hline CSR & $0.517^{* * *}$ & $0.303^{* * *}$ & $0.276^{* *}$ & $0.233^{* * *}$ & $0.047^{*}$ & $0.206^{*}$ \\
& -5.664 & -3.031 & -1.993 & -2.692 & -1.364 & -1.796 \\
\hline SIZE & $1.586^{* * *}$ & $0.798^{* * *}$ & 0.679 & $0.421^{*}$ & $0.160^{* *}$ & 0.477 \\
& -6.463 & -3.203 & -1.408 & -1.806 & -1.872 & -1.197 \\
\hline LEV & $-0.063^{* * *}$ & $-0.086^{* * *}$ & 0.005 & -0.013 & -0.001 & -0.023 \\
& $(-5.300)$ & $(-6.159)$ & -0.266 & $(-1.182)$ & $(-0.142)$ & $(-1.640)$ \\
\hline F-VALUE & $39.734^{* * *}$ & $19.940^{* * *}$ & $2.613^{*}$ & $4.643^{* * *}$ & $2.381^{* *}$ & $3.319^{* * *}$ \\
\hline
\end{tabular}

This study has several empirical limitations, which can be addressed in future research. First, the current empirical estimation is not immune to the endogeneity problem. This can be resolved using the solution proposed by [60]. Second, small firms are more likely to be connected to small, relatively powerless rivals, whereas larger firms are likely to be connected to larger, powerful parties; thus, an alternative measure for firm size could be considered [61]. Lastly, the results may be more fruitful if the channels are considered through which CSR activities affect firms' outcomes. One important channel could be corporate governance mechanisms [62], such as the impact of board composition or market competition. We leave these issues for future research.

\section{Conclusions}

The purpose of this study is to evaluate sustainable development activities focused on CSR activities in Korea. It does so in three ways: measuring CP by CSR, understanding the effects of CSR on $\mathrm{CP}$ by industry, and using case studies to examine Korean firms' recent CSR activities. Many previous studies have argued that CSR has a positive financial impact, that it has not been effective in increasing $\mathrm{CP}$, or that it worsens firms' performance. In contrast, several studies have stated that CP and CSR are not correlated. Therefore, by evaluating CSR in Korea using data over a four-year period, from 2012 to 2015, this paper presents an overview of CSR in Korea.

There are several differences between this and prior studies. First, this study uses the most recent version of the KEJI evaluation score, published toward the end of 2016. This is also a complex study, including case studies and empirical research to show the overall implementation and response to CSR by Korean firms. The results are as follows.

This study evaluated CSR in Korea over four years in three ways. First, the impact of CSR in Korea on CP is determined using the ROA for the accounting effect, and Tobin's $Q$ for the financial result. This generated empirical studies on the correlation using the regression method. The results show that CSR has a positive effect on CP for all four years. Furthermore, the effects of CSR on $\mathrm{CP}$ vary by industry for the sample period. Manufacturing experiences a greater impact on $\mathrm{CP}$ by CSR than does the service/nonmanufacturing industry. To examine this further, another industrial 
comparison between consumption goods and industrial products was performed. The results show that the CP of businesses involved in consumption goods is affected significantly by CSR in the sample. This is because consumption goods are sensitive to customers' responses, and because firms dealing in industrial goods normally deal with other companies, and not directly with consumers. Although manufacturers of industrial goods implement CSR, it has not had an effective impact on their CP.

This study employs two financial approaches, namely, the ROA and Tobin's $Q$, which contribute to future research because of the four years of evaluation research, including recent CSR data. CSR has a positive effect on $\mathrm{CP}$ over the sample period, as shown in the three case studies of Korean firms. The case studies reveal the efforts of companies to conduct CSR and the vision they have implemented for CSR.

Specifically, this study makes the following contributions to the literature, relative to prior research. First, we corroborate the positive relation between CSR and CP using both accounting-based and market-based measures. In addition, we contribute to the CSR literature by using recent data, which are not yet extensively investigated, observing CSR in South Korea from various perspectives. Using an empirical study on CSR performance related to CP, it is easy to determine whether CSR is beneficial for a country or a corporation. This study is one of few to examine whether CSR activity benefits Korean firms' CP. Previous studies have examined the effect of CSR on CP, but the results have been contradictory. Some argue that CSR activities do not benefit companies. However, in recent years, as CSR has become part of the Korean business culture, its relationship with corporate values needs to be examined.

There are several limitations to this study. First, the CSR data are taken from the top 200 CSR firms, published by the Citizens' Coalition for Economic Justice. In the Korea Stock Market, there are more than 800 corporations. Thus, using the results for the top 200 firms on the KEJI may restrict our understanding of the results. In addition, the KEJI is published every two years, which makes it difficult to compare and research CSR and CP. Therefore, there may be real factors that differ from the research results. Second, for the same activities among firms, the results would overlap, where the results for some decisions are subjectively directed. Lastly, the estimators in the multivariate regression analyses might be biased because of a potential endogeneity issue between CSR and firm financial performance. We suggest that one consider performing several robustness tests using instrumental variables, lead-lag dependent-independent variables, or a dynamic model; we leave this to future research.

Author Contributions: C.Y.C. designed the research. D.C. performed research and analyzed the data. C.Y.C., D.C. and J.Y. wrote the paper. All authors read and approved the final manuscript.

Funding: This work was supported by the research program of Kookmin University in Korea.

Acknowledgments: We would like to thank the editor and the three reviewers for their helpful comments and suggestions.

Conflicts of Interest: The authors declare no conflict of interest.

\section{References}

1. Park, H. Summary of Result for CSR Contribution Rate in 2015-2016. Available online: http://www.fki.or. kr/FkiAct/Promotion/Report/View.aspx?content_id=564ac821-792c-44dc-a1ea-3c75df445f48 (accessed on 5 January 2017).

2. Carroll, A.; Shabana, K. The business case for corporate social responsibility: A review of concepts, research and practice. Int. J. Manag. Rev. 2010, 12, 85-105. [CrossRef]

3. Carroll, A.B. The pyramid of corporate social responsibility: Toward the moral management of organizations stakeholder. Bus. Horiz. 1991, 34, 39-48. [CrossRef]

4. Stewart, L. Reputation and corporate responsibility. J. Commun. Manag. 2013, 7, 356-366.

5. Mayer, R.; Gavin, M. Trust in management and performance: Who minds the shop while the employees watch the boss? Acad. Manag. J. 2005, 48, 874-888. [CrossRef]

6. Maignan, X.; Ferrell, Y. Corporate citizenship as a marketing instrument: Concepts, evidence and research directions. Eur. J. Mark. 2013, 35, 457-484. [CrossRef] 
7. Chung, C.Y.; Cho, S.J.; Ryu, D.; Ryu, D. Institutional blockholders and corporate social responsibility. Asian Bus. Manag. 2019, 18,1-44. [CrossRef]

8. Orlitzky, M.; Schmidt, F.L.; Rynes, S.L. Corporate social and financial performance: A meta-analysis. Organ. Stud. 2003, 24, 403-441. [CrossRef]

9. McWilliams, A.; Siegal, D. Corporate social responsibility and financial performance: Correlation or misspecification? Strateg. Manag. J. 2000, 21, 603-609. [CrossRef]

10. Zaccheaus, S.; Oluwagbemiga, O.; Olugbenga, O. Effects of corporate social responsibility performance (CSR) on stock prices: Empirical study of listed manufacturing companies in Nigeria. IOSR-JBM 2014, 16, 12-17. [CrossRef]

11. Lee, H. Strategy changes and its responds methods (Social welfare). Educ. Policy Forum 2008, 178-183.

12. Choi, C. The Research for Korean Firms' Social Contribution Activities and Methods for Effective Communication System. Master's Thesis, Han-Yang University, Seoul, Korea, 2002.

13. An, C. Social Framing for Corporate Social Responsibility. Ph.D. Thesis, Kyung-Hee University, Seoul, Korea, 2013.

14. McGuire, J.; Sundgren, A.; Schneeweis, T. Corporate social responsibility and firm financial performance. Acad. Manag. J. 1988, 31, 854-872.

15. Porter, M.; Kramer, M. Strategy and society: The link between competitive advantage and corporate social responsibility. Harv. Bus. Rev. 2006, 84, 78-82. [PubMed]

16. Dahlsrud, A. How corporate social responsibility is defined: An analysis of 37 definitions. Corp. Soc. Resp. Environ. Manag. 2008, 15, 1-13. [CrossRef]

17. Kim, S. Theoretical research changes of corporate social responsibility. Corp. Bus. Res. 2009, 16, 1-25.

18. Frederick, W.C. Corporation Be Good! The Story of Corporate Social Responsibility; Dogear Publishing: Indianapolis, IN, USA, 2006; p. 37.

19. Friedman, M. The social responsibility of business is to increase its profits. N. Y. Times Mag. 1970, 32/33, $122-126$.

20. The Federation of Korea Industries. CSR Organization and Political View in the World; The Federation of Korea Industries: Seoul, Korea, 2008.

21. Kim, K. The Research for Relationship between CSR and Corporate Performances. Master's Thesis, Kyung-Hee University, Seoul, Korea, 2016.

22. Turban, D.B.; Greening, D.W. Corporate social performance and organizational attractiveness to prospective employees. Acad. Manag. J. 1997, 40, 658-672.

23. Peterson, D. The relationship between perceptions of corporate citizenship and organizational commitment. Bus. Soc. 2004, 43, 296-319. [CrossRef]

24. Dawkins, J. Corporate responsibility: The communication challenge. J. Commun. Manag. 2004, 9, 108-119. [CrossRef]

25. Valentine, S.; Barnett, T. Ethics code awareness, perceived ethical values, and organizational commitment. JPSSM 2003, 23, 359-367.

26. Waddock, S.; Graves, S. The corporate social performance-financial performance link. Strateg. Manag. J. 1997, 18, 303-319. [CrossRef]

27. Mishra, S.; Suar, D. Does corporate social responsibility influence firm performance of Indian companies? J. Bus. Ethics 2010, 95, 571-601. [CrossRef]

28. Park, H. The evaluation of Korean CSR promotion policy. Create. Innov. 2008, 1, $269-296$.

29. Kim, J.; Byun, S. CSR Movements and Strategic CSR. Fall Thesis, The International Business Management Conference of South Korea, Seoul, Korea, 2009; pp. 285-316.

30. Sa, D.; Park, B. Developed countries' social corporate policy and Korean view: Comparison among the UK, the US, and South Korea. Policy Dev. Res. 2011, 11, 81-108.

31. Jung, Y. Analysis of performance factors of corporate social responsibility and prediction of sustainable development. Korean Manag. Conf. 2012, 25, 2065-2089.

32. Moon, $\mathrm{H}$. The relationship between ethical management and real-based earnings management. Acc. J. S. Korea 2007, 16, 81-106.

33. Jang, J.; Choi, H. The relationship between corporate social responsibility and financial performance. Korean Manag. Conf. 2010, 23, 633-648. 
34. Lee, K. The Impact of CSR into Accounting Profits and Financial Performances: Focused on KEJI Index. Ph.D. Thesis, Korea University, Seoul, Korea, 2011.

35. Park, J.; Choi, J. The study for relationship between corporate environment performances and financial performances. Manag. Res. 2004, 33, 1461-1487.

36. Wi, P. The empirical study for relationship between listed firms' social responsibility and corporates values. Manag. Res. 2006, 21, 97-125.

37. Cho, S.J.; Chung, C.Y.; Young, J. Study on the relationship between CSR and financial performance. Sustainability 2019, 11, 343. [CrossRef]

38. Kwak, Y. The Effects of Corporate Social Responsibility into Corporate Performances. Ph.D. Thesis, Inha University, Incheon, Korea, 2013.

39. Cho, E.; Park, H. Is CSR really profitable? Evidence from Korea. JABR 2015, 31, 2167-2186. [CrossRef]

40. AmorePacific. A More Beautiful World; Sustainable Report 2016; AmorePacific Group, Co.: Seoul, Korea, 2017.

41. Chung, C. How South Korea's AmorePacific Became One of the World's Most Innovative Companies 2015. Available online: https:/www.forbes.com/sites/gracechung/2015/08/19/how-south-koreas-amorepacificbecame-one-of-the-worlds-most-innovative-companies/\#38814c52b2b1 (accessed on 14 March 2017).

42. Sa, D. The evaluation of Korean firms' corporate social responsibility activities: Surpassing strategic philanthropy. Korean Admin Policy Res. 2011, 9, 1-28.

43. Kim, D.H.; Jang, B.K.; Hong, S.C.; Moon, H.J.; Lee, D.H.; Oh, H.J. Assessment of the Naktong River pollution after phenol spillage from the Kumi Industrial Estates. J. Prev. Med. Public Health 1993, 26, 268-281.

44. Shin, D. Nakdong River Phenol Scandal 2: Beer Bubbles on the street: Boycott to OB Doosan Beer. Newsmak. Kyunghyang Newsp. 2006, 15, 52-55.

45. De Gilder, D.; Schuyt, T.N.; Breedijk, M. Effects of an employee volunteering program on the work force: The ABN-AMRO case. J. Bus. Ethics 2005, 61, 143-152. [CrossRef]

46. Waddock, S.A.; Smith, N. Relationships: The real challenge of corporate global citizenship. Bus. Soc. Rev. 2000, 105, 47-62. [CrossRef]

47. Hong, H.; Kubik, J.D.; Scheinkman, J.A. Financial Constraints on Corporate Goodness; National Bureau of Economic Research: Cambridge, MA, USA, 2012; No. w18476.

48. McWilliams, A.; Siegel, D. Corporate social responsibility: A theory of the firm perspective. Acad. Manag. Rev. 2001, 26, 117-127. [CrossRef]

49. El Ghoul, S.; Guedhami, O.; Kwok, C.C.; Mishra, D.R. Does corporate social responsibility affect the cost of capital? J. Bank Financ. 2011, 35, 2388-2406. [CrossRef]

50. Surroca, J.; Tribo, J.A. Managerial entrenchment and corporate social performance. J. Bus. Finan. Acc. 2008, 35, 748-789. [CrossRef]

51. Campbell, J.L. Why would corporations behave in socially responsible ways? An institutional theory of corporate social responsibility. Acad. Manag. Rev. 2007, 32, 946-967. [CrossRef]

52. Petersen, M.A. Estimating standard errors in finance panel data sets: Comparing approaches. Rev. Financ. Stud. 2009, 22, 435-480. [CrossRef]

53. Ambec, S.; Lanoie, P. Does it pay to be green? A systematic overview. Acad. Manag. Perspect. 2008, $22,45-62$.

54. Caputo, F.; Veltri, S.; Venturelli, A. A conceptual model of forces driving the introduction of a sustainability report in SMEs: Evidence from a case study. Int. Bus. Res. 2017, 10, 39-50. [CrossRef]

55. Flammer, C. Does corporate social responsibility lead to superior financial performance? A regression discontinuity approach. Manag. Sci. 2015, 61, 2549-2568. [CrossRef]

56. Hart, S.L.; Ahuja, G. Does it pay to be green? An empirical examination of the relationship between emission reduction and firm performance. Bus. Strateg. Environ. 1996, 5, 30-37. [CrossRef]

57. King, A.A.; Lenox, M.J. Does it really pay to be green? An empirical study of firm environmental and financial performance. J. Ind. Ecol. 2001, 5, 105-116. [CrossRef]

58. Lins, K.V.; Servaes, H.; Tamayo, A. Social capital, trust, and firm performance: The value of corporate social responsibility during the financial crisis. J. Financ. 2017, 72, 1785-1824. [CrossRef]

59. Choi, W.Y.; Lee, H.S.; Hong, C.S. Corporate social responsibility and firm value: Focused on corporate contributions. Korean Manag. Rev. 2009, 38, 407-432.

60. Li, F. Endogeneity in CEO power: A survey and experiment. Invest. Anal. J. 2016, 45, 149-162. [CrossRef] 
61. Dang, C.; Li, Z.F.; Yang, C. Measuring firm size in empirical corporate finance. J. Bank Financ. 2018, 86, 159-176. [CrossRef]

62. Li, Z.F. Mutual monitoring and corporate governance. J. Bank Financ. 2014, 45, 255-269.

(C) 2019 by the authors. Licensee MDPI, Basel, Switzerland. This article is an open access article distributed under the terms and conditions of the Creative Commons Attribution (CC BY) license (http://creativecommons.org/licenses/by/4.0/). 